\title{
Respon Pertumbuhan Stek Anggur (Vitis vinifera L.) terhadap Pemberian Beberapa Konsentrasi Ekstrak Bawang Merah (Allium ascalonicum L.)
}

\author{
Growth Response of Grape (Vitis vinifera L.) Cutting after Shallot (Allium \\ ascalonicum L.) extract application \\ Tri Utami $^{1}$, Hermansyah ${ }^{1 *}$, Merakati Handajaningsih ${ }^{1}$ \\ ${ }^{1} J u r u s a n$ Budidaya Pertanian Fakultas Pertanian Universitas Bengkulu. \\ *:mamanhermansyah69@yahoo.co.id
}

\begin{abstract}
The purpose of this study was to determine the optimum concentration of shallot extract to the growth of grape cuttings grape cuttings. This study was conducted from September to December 2015 in the city of Bengkulu. This research used Completely Randomized Design with a single factor and five replications. Treatment concentrations of $0 \%$ (control), shallot extract concentration of $25 \%, 75 \%$ and $100 \%$. The variables measured were the time to sprout, shoot height, the number of leaves, number of roots, fresh weight and dry weight of cuttings. The results showed that the concentration of shallot extract $100 \%$ concentration enhances the growth of grape cutting, time to sprout, and the concentration of extract $50 \%$ increase shoot height and number of leaves on grape cuttings.
\end{abstract}

Keywords: shallot, extract onion, grape, cuttings

\begin{abstract}
ABSTRAK
Tujuan penelitian ini adalah untuk menentukan stek anggur yang optimum pada pemberian konsentrasi ekstrak bawang merah yang optimum bagi pertumbuhan stek anggur. Penelitian ini dilaksanakan bulan September sampai Desember 2015 di Kota Bengkulu. Penelitian ini menggunakan metode Rancangan Acak Lengkap (RAL) dengan faktor tunggal dan lima ulangan. Perlakuan konsentrasi yaitu $0 \%$ (kontrol), konsentrasi ekstrak bawang merah $25 \%, 75 \%$ dan $100 \%$. Variabel yang diamati adalah saat tumbuh tunas, tinggi tunas, jumlah daun, jumlah akar, bobot basah bibit dan bobot kering bibit. Hasil penelitian menunjukkan bahwa pemberian konsentrasi ekstrak bawang merah konsentrasi $100 \%$ mampu meningkatkan pertumbuhan setek anggur pada variabel saat tumbuh tunas,dan pada konsentrasi ekstrak bawang merah $50 \%$ meningkatkan tinggi tunas dan jumlah daun pada stek anggur.
\end{abstract}

Kata kunci : ekstrak bawang merah, konsentrasi, stek anggur

\section{PENDAHULUAN}

Anggur (Vitis vinifera L.) merupakan tanaman buah-buahan yang sangat banyak digemari masyarakat Indonesia. Buah ang- gur selain dikonsumsi sebagai buah segar dapat juga dibuat berbagai olahan seperti jelly, minuman anggur, kismis, dan minyak biji anggur. Selain kaya nutrisi, anggur mampu membersihkan toksin-toksin 
di dalam hati, membantu memperbaiki fungsi ginjal, pembentukan sel darah, antivirus dan antikanker, serta mampu mencegah kerusakan gigi. Anggur bersifat basa sehingga dapat menetralkan darah yang terlalu asam dan berefek merugikan tubuh (Wiryanta, 2007). Penelitian di China mengungkapkan anggur merah digunakan untuk menurunkan kadar kolesterol dan digunakan pula melindungi sel dari sinyal proinflamasi melalui mekanisme pengaturan distribusi kolesterol (Fauzi, 2009).

Berdasarkan data statistik produksi tanaman anggur di Indonesia mengalami penurunan dari tahun ke tahun. Pada tahun 2011 produksi anggur mencapai 11938 ton, pada tahun 2012 mengalami penurunan menjadi 10601 ton, dan pada tahun 2013 mengalami penurunan mencapai 9 473 ton. Pada tahun 2014 mengalami kenaikan menjadi 11153 ton, namun peningkatan produksi ini tidak terlalu signifikan dibandingkan hasil produksi pada tahun 2011 (BPS, 2015).

Salah satu faktor penyebab masih rendahnya produksi anggur di Indonesia, umumnya tanaman anggur ditanam sebagai tanaman pekarangan dan sebagai tanaman sela di antara jenis tanaman lainnya, sampai saat ini budidaya tanaman anggur belum maksimal pengelolaannya. Dalam upaya perbanyakan tanaman anggur dapat dilakukan secara vegetatif yaitu melalui stek batang (Rahardja dan Wiryanta, 2003). Perbanyakan tanaman dengan stek dibatasi oleh sedikitnya stek yang membentuk akar dan lambatnya pertumbuhan tunas. Hal ini dapat disebabkan oleh kurangnya hormon pembentuk akar dan pemilihan media perakaran pangkal stek yang kurang tepat. Sebagai pengganti auksin sintetis dapat digunakan bawang merah (Muswita, 2011).

Menurut Marfirani (2014), umbi bawang merah mengandung hormon pertumbuhan berupa hormon auksin dan gibberellin, sehingga dapat memacu pertum- buhan stek. Hasil penelitian Siswanto et al. (2010), pemberian auksin sebagai zat pengatur tumbuh dapat meningkatkan presentase stek yang membentuk akar, mempercepat inisiasi akar, dan menyeragamkan perakaran stek. Siregar et al. (2015), menyatakan pemberian bawang merah dengan konsentrasi 75\% memberikan hasil terbaik untuk pertumbuhan panjang akar, panjang tunas dan jumlah tunas pada stek mawar. Hasil penelitian Sekta (2005) juga menunjukkan bawang merah memberikan pengaruh yang nyata tehadap panjang tunas, jumlah daun, tingkat kehijauan daun dan berat kering tunas pada stek cabe jawa. Zat pengatur tumbuh yang sering digunakan untuk perakaran adalah auksin, namun relatif mahal dan sulit diperoleh. Sebagai pengganti auksin sintesis dapat digunakan bawang merah.

Penggunaan ekstrak bawang merah lebih menguntungkan karena memberikan kemudahan kepada petani untuk memperoleh ZPT yang praktis dari sumber daya alam yang ramah lingkungan (Khair et al, 2013). Kelangsungan hidup tanaman sangat ditentukan oleh pembentukan akar, makin cepatnya pembentukan akar oleh organ-organ vegetatif memungkinkan tanaman untuk hidup. Oleh karena itu pemberian zat pengatur tumbuh berupa auksin dapat memacu perkembangan akar adventif dan sering digunakan pada stek tanaman (Mayasari et al., 2012). Tujuan dari penelitian ini adalah untuk menentukan pertumbuhan stek anggur yang optimum pada pemberian konsentrasi ekstrak bawang merah.

\section{METODE PENELITIAN}

Penelitian ini dilaksanakan bulan September sampai Desember 2015 di Jln. Beringin Raya Kota Bengkulu dengan ketinggian $6 \mathrm{~m}$ di atas permukaan laut. Rancangan yang digunakan Rancangan Acak 
Lengkap (RAL) dengan perlakuan: $\mathrm{A}_{0}=$ tanpa Ekstrak Bawang Merah (kontrol), $\mathrm{A}_{1}=$ Ekstrak Bawang Merah konsentrasi $25 \%, \mathrm{~A}_{2}=$ Ekstrak Bawang Merah konsentrasi $50 \%, \mathrm{~A}_{3}=$ Ekstrak Bawang Merah konsentrasi $75 \%$, dan $\mathrm{A}_{4}=$ Ekstrak Bawang Berah konsentrasi $100 \%$. Setiap perlakuan diulang lima kali dan setiap unit perlakuan terdiri dari empat tanaman sehingga di peroleh 100 sampel di pembibitan.

\section{Pembuatan naungan, penanaman stek dan pemeliharaan}

Naungan dibuat dengan menggunakan bambu dan bahan atap dari daun rumbia. Naungan dibuat menghadap ke arah Timur-Barat dengan tinggi bagian Timur $1.50 \mathrm{~m}$ dan tinggi bagian Barat 1.30 $\mathrm{m}$. Media tanam yang digunakan adalah tanah, pupuk kandang, dan sekam padi dengan perbandingan volume 1:1:1. Campuran media tanam dimasukkan ke polibag dengan ukuran $10 \mathrm{~cm}$ x $20 \mathrm{~cm}$. Tanaman anggur yang di gunakan adalah jenis anggur Probolinggo. Bahan stek diambil dari batang yang sudah cukup tua dan memiliki diameter sama sekitar $0.5 \mathrm{~cm}$ dengan warna kecoklatan, sehat dan bebas dari serangan hama penyakit. Batang anggur dipotong sepanjang $25 \mathrm{~cm}$ dan direndam selama 12 jam setinggi $3 \mathrm{~cm}$ dalam ZPT yang berasal dari ekstrak bawang merah sesuai dengan konsentrasi perlakuan (Siswanto et al., 2008). Stek ditanam $10 \mathrm{~cm}$ dari pangkal dan selanjutnya polibag diletakkan di dalam naungan.

Untuk menjaga kelembaban stek, maka dilakukan penyiraman pagi dan sore hari. Penyiangan gulma yang tumbuh dalam polibag maupun di dalam naungan dilakukan secara manual. Beberapa variabel yang diamati terkait dengan perlakuan adalah saat tumbuh tunas, tinggi tunas, jumlah daun, jumlah akar, panjang akar, bobot basah bibit, bobot kering bibit. Penimbangan bobot kering bibit dilakukan setelah dioven selama 48 jam dengan suhu $70^{\circ} \mathrm{C}$ hingga berat konstan.

Data yang diperoleh dianalisis secara statistik dengan menggunakan analisis keragaman (uji F) pada taraf 5\% jika terdapat pengaruh nyata antar perlakuan pada variabel yang diamati maka dilanjutkan dengan uji BNT pada taraf 5\%.

\section{HASIL DAN PEMBAHASAN}

Berdasarkan hasil penelitian yang telah dilakukan diketahui bahwa pertumbuhan stek anggur yang telah diberi perlakuan dengan beberapa konsentrasi ekstrak bawang merah mengalami hambatan dalam pertumbuhan setelah fase tumbuh tunas. Hal ini di sebabkan kondisi pada lingkungan pembibitan dan media memiliki kandungan air tanah yang berlebihan. Pertumbuhan stek terganggu karena terlalu banyak menyerap air tanah. Proses transpirasi pada stek tidak terjadi secara optimal, sehingga menyebabkan tidak terbentuknya akar pada stek. Menurut Suhartono et al. (2008) kandungan air tanah rendah dapat mengakibatkan rendahnya konsentrasi unsur hara yang ada dilarutan tanah. Rendahnya konsentrasi unsur hara yang ada didalam larutan tanah menyebabkan kebutuhan akan unsur hara tanaman tidak tercukupi dan mengakibatkan kompetisi hara antar tanaman, begitu pula sebaliknya air yang berlebihan, akan menyebabkan batang tanaman menjadi busuk. Kemampuan sel-sel tanaman dalam menyimpan air dalam dinding sel sangat terbatas. Air yang berlebihan, akan menyebabkan dinding sel menjadi pecah, selanjutnya sel-sel tanaman akan mati dan tanaman akan membusuk.

Suhu selama penelitian berlangsung yaitu memiliki rata-rata $31.38^{\circ} \mathrm{C}$ pada siang hari dan pada sore hari $29.17^{\circ}$ C. Kelembaban udara juga mempengaruhi gagalnya pertumbuhan stek anggur pada peneliti- 
an ini. Kelembaban udara dalam naungan rata-rata $24.28 \%$ pada siang hari dan pada sore hari $29.54 \%$. Kelembaban udara pada kisaran tersebut sangat rendah untuk pertumbuhan stek, sehingga menyebabkan pertumbuhan akar dan tunas terhambat.

Berdasarkan analisis varian dapat dilihat bahwa peubah saat tumbuh tunas, tinggi tunas dan jumlah daun, berpengaruh nyata terhadap pemberian konsentrasi ekstrak bawang merah yang diberikan pada stek anggur (Tabel 1). Hal ini menunjukkan bahwa pemberian ekstrak bawang memberikan respon yang baik pada variabel saat tumbuh tunas, tinggu tunas dan jumlah daun.

Pemberian zat pengatur tumbuh alami berupa auksin untuk merangsang pertumbuhan stek, dapat diperoleh dari ekstrak umbi bawang merah. Ekstrak bawang merah mampu menstimulasi pembentukan kalus, dimana kalus merupakan awal dari pembentukan akar pada stek. Hal ini karena bawang merah mengandung hormon auksin yang berfungsi menstimulasi pertumbuhan akar. Hal ini sejalan dengan Rahayu dan Berlian (1999) dalam Siskawati et al. (2013), yang menyatakan umbi bawang merah mengandung mengandung zpt auksin dan rhizokalin yang dapat merangsang pertumbuhan akar, vitamin B1 (Thiamin) untuk pertumbuhan tunas, asam nikotinat sebagai koenzim, serta riboflavin untuk pertumbuhan.

Pada grafik pertumbuhan stek (Gambar 1) dapat dilihat bahwa pada variabel jumlah daun dan tinggi tunas menunjukkan pertumbuhan stek paling baik yaitu pada perlakuan konsentrasi ekstrak bawang merah 50\% dibandingkan dengan perlakuan konsentrasi lainnya. Pada variabel saat tumbuh tunas hasil paling baik ditunjukkan pada perlakuan tanpa konsentrasi ekstrak bawang merah (kontrol), namun hasil ini tidak signifikan jika dibandingkan dengan hasil perlakuan ekstrak bawang merah konsentrasi 50\%. Perlakuan peningkatan konsentrasi ekstrak bawang merah 75\% dan $100 \%$ menyebabkan menurunnya pertumbuhan stek. Hasil ini mengindikasikan bahwa konsentrasi ekstrak bawang merah konsentrasi $50 \%$ adalah perlakuan paling baik dan optimal untuk pertumbuhan stek anggur. Hasil penelitian Halimursyadah et al. (2014) pemberian auksin memberikan hasil yang berbeda disebabkan setiap jenis bagian tanaman memiliki respon yang tidak sama terhadap penyetekan yang dapat mempengaruhi pertumbuhannya. Menurut Leovici et al. (2014), penggunaan zat pengatur tumbuh yang berlebihan akan bersifat racun yang mengakibatkan pertumbuhan stek terhambat, bahkan mengakibatkan stek gagal tumbuh. Hormon dengan konsentrasi yang tepat dapat menggiatkan pertumbuhan bibit, tetapi jika konsentrasinya semakin tinggi atau terlalu rendah justru akan menghambat pertumbuhan bibit (Tabel 2).

Hasil uji lanjut BNT terhadap variabel saat tumbuh tunas menunjukkan bahwa pemberian ekstrak bawang merah memberikan perbedaan sangat nyata. Pada perlakuan tanpa konsentrasi ekstrak bawang merah (kontrol) memberikan hasil paling baik pada variabel saat tumbuh tunas dibandingkan dengan perlakuan konsentrasi lainnya, namun hasil ini tidak signifikan jika dibandingkan dengan hasil perlakuan ekstrak bawang merah konsentrasi 50\%.

Menurur Heddy (2002), perbedaan kemampuan tanaman dalam memanfaatkan faktor-faktor lingkungan seperti air, $\mathrm{CO}_{2}$, suhu, energi matahari dan sebagainya, mempengaruhi kemampuan tanaman melakukan fotosintesis, dengan demikian akan berpengaruh terhadap pertumbuhan tanaman, terutama tunas. Mashudi et al. (2008), menyatakan bahwa kondisi lingkungan sangat mempengaruhi pertumbuhan tunas antara lain kelembaban, unsur hara atau kesuburan media dan penyinaran cahaya ma- 
Tabel 1. Hasil analisis keragaman terhadap semua variabel yang diamati

\begin{tabular}{lcc}
\hline \multicolumn{1}{c}{ Variabel yang diamati } & F. hitung & F. tabel \\
\hline Saaat tumbuh tunas & $4.78^{* *}$ & 2.87 \\
Tinggi tunas & $3.71 *$ & 2.87 \\
Jumlah daun & $3.95 *$ & 2.87 \\
Jumlah akar & $1.09 \mathrm{~ns}$ & 2.87 \\
Panjang akar & $1.79 \mathrm{~ns}$ & 2.87 \\
Bobot basah bibit & $1.38 \mathrm{~ns}$ & 2.87 \\
Bobot kering bibit & $1.35 \mathrm{~ns}$ & 2.87 \\
\hline
\end{tabular}

Keterangan : ${ }^{* *}=$ sangat berpengaruh nyata, ${ }^{*}=$ berpengaruh nyata, $\mathrm{ns}=$ tidak berpengaruh nyata

Tabel 2. Uji BNT taraf 5\% terhadap variabel saat tumbuh tunas, tinggi tunas, dan jumlah daun

\begin{tabular}{lccc}
\hline Perlakuan ekstrak bawang merah & Saat Tumbuh Tunas & Tinggi Tunas & Jumlah Daun \\
\hline $0 \%$ & $3.167 \mathrm{a}$ & $2.497 \mathrm{ab}$ & $1.550 \mathrm{ab}$ \\
$25 \%$ & $2.230 \mathrm{c}$ & $1.704 \mathrm{~b}$ & $1.235 \mathrm{bc}$ \\
$50 \%$ & $2.983 \mathrm{ab}$ & $3.508 \mathrm{a}$ & $1.953 \mathrm{a}$ \\
$75 \%$ & $2.264 \mathrm{bc}$ & $1.977 \mathrm{~b}$ & $1.203 \mathrm{bc}$ \\
$100 \%$ & $1.915 \mathrm{c}$ & $1.367 \mathrm{~b}$ & $0.980 \mathrm{c}$ \\
\hline
\end{tabular}

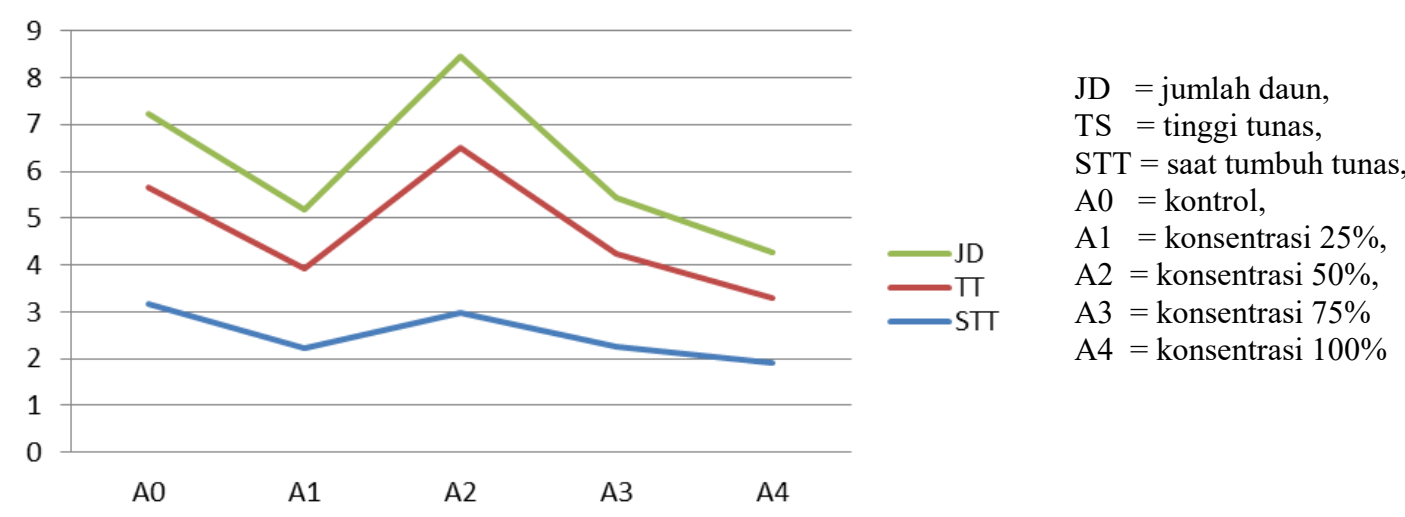

Konsentrasi ekstrak bawang merah

Gambar 1. Grafik pertumbuhan stek anggur pada beberapa konsentrasi ekstrak bawang merah

tahari. Selain media, pembentukkan tunas juga dipengaruhi oleh hormon sitokinin. Hal ini ditegaskan oleh Lakitan (1996), bahwa hormon sitokinin ditransport secara akropetal melalui bagian xilem kebagian atas tanaman. Sitokinin akan merangsang pembelahan sel pada tanaman dan sel-sel yang membelah tersebut akan berkembang menjadi tunas.

Hasil uji lanjut BNT terhadap variabel tinggi tunas menunjukkan hasil berbeda nyata. Tinggi tunas terbaik terdapat pada perlakuan konsentrasi ekstrak bawang merah 50\% dibandingkan dengan perlakuan konsentrasi lainnya. Diduga bahwa tinggi tunas dipengaruhi oleh banyaknya jumlah akar pada stek serta panjang akar yang mampu menyerap unsur hara didalam tanah menjadi lebih banyak serta karena ekstrak bawang merah mengandung auksin yang berperan dalam pemanjangan sel. Hasil ini mengindikasikan bahwa konsentrasi ekstrak bawang merah $50 \%$ adalah dosis paling tepat untuk menghasilkan tinggi tu- 
nas terbaik. Hasil penelitian Sudrajad dan Widodo (2011), menyatakan respon zat pengatur tumbuh berkaitan erat dengan konsentrasinya, pada konsentrasi yang tepat akan dapat mengatur proses fisiologis tanaman sehingga akan dapat merangsang pertumbuhannya, sedangkan pada tingkat konsentrasi yang tinggi atau terlalu rendah justru akan dapat menghambat proses pertumbuhan tanaman. Hal ini sesuai dengan Sumiasri et al. (2003) dalam Ardana (2009), bahwa tanaman memerlukan konsentrasi auksin yang sesuai dan tepat untuk pertumbuhannya. Lakitan (1996) dalam Hafizah (2014), menyatakan bahwa pertumbuhan dan perkembangan sel tergantung dari suplai unsur hara yang diberikan oleh akar untuk metabolisme dan sintesis protein sehingga menyebabkan pertambahan panjang tunas.

Hasil uji lanjut BNT terhadap variabel jumlah daun menunjukkan hasil berbeda nyata. Jumlah daun paling banyak terdapat pada perlakuan konsentrasi ekstrak bawang merah 50\% dibandingkan dengan perlakuan konsentrasi lainnya. Peningkatan konsentrasi ekstrak bawang merah $75 \%$ dan $100 \%$ menyebabkan sedikitnya jumlah daun pada stek. Menurut Yuniasuti et al. (2007) daun merupakan organ vegetatif, pertumbuhannya dipengaruhi oleh kandungan $\mathrm{N}$ dalam media, daun berfungsi sebagai penghasil fotosintat yang sangat diperlukan tanaman sebagai sumber energi dalam proses pertumbuhan dan perkembangan.

Hasil penelitian Lusiana et al. (2012) pemberian urine sapi berpengaruh nyata terhadap jumlah daun tanaman sirih merah. Selain hormon auksin yang terdapat dalam urine sapi juga terdapat hormon sitokinin yang berfungsi merangsang pembentukan daun pada stek. Cepatnya muncul tunas pada stek maka proses pertumbuhan pada stek akan lebih cepat pula sehingga pertambahan jumlah daun yang dihasil- kan akan lebih banyak. Diduga kandungan auksin pada larutan ekstrak bawang merah memacu pertumbuhan stek. selain berperan pada pembentukan tunas, tinggi tunas dan pembentukan akar juga berperan dalam pembentukan daun. Jumlah daun terbanyak menunjukkan tanaman mengalami pertum-buhan dan perkembangan yang lebih baik.

\section{KESIMPULAN}

Pemberian konsentrasi ekstrak bawang merah memberikan pengaruh nyata pada variabel saat tumbuh tunas, tinggi tunas dan jumlah daun. Konsentrasi ekstrak bawang merah $50 \%$ adalah dosis paling optimum untuk pertumbuhan stek anggur dan kondisi lingkungan pembibitan, media tanam, serta suhu dan kelembaban yang rendah dapat menghambat proses pertumbuhan stek.

\section{DAFTAR PUSTAKA}

Ardana, R. C. 2009. Pengaruh macam zat pengatur tumbuh dan frekuensi penyemprotan terhadap pertumbuhan awal bibit gelombang cinta (Anthurium plowmanii). Skripsi. Fakultas Pertanian UNS Surakarta. (tidak dipublikasikan).

Badan Pusat Statistik Indonesia. 2015. Statistik produksi tanaman buahbuahan. http://www.pertanian.go.id/ EIS-ASEM-HORTI-2014/ProdBuah-ASEM HORTI2014.pdf. Diakses 02 Juli 2015.

Fauzi, R. 2009. Efek jus buah anggur merah (Vitis vinifera L.) terhadap penghambatan peningkatan kadar LDL kolesterol darah tikus putih (Rattus 
norvegicus). Skripsi. Universitas Sebelas Maret. Surakarta. (tidak dipublikasikan).

Hafizah, N. 2014. Pertumbuhan stek mawar (Rosa damascena Mill.) pada waktu perendaman dalam larutan urine sapi. J. Ziraa'ah 39(3):129-13.

Halimursyadah., Hasanuddin, dan Nurfadillah. 2014. Perbanyakan vegetatif tanaman nanas (Ananas comusus L. Merr) dari sumber stek berbeda dan konsentrasi auksin. J. Ilmiah Agr IBA (2):99-106.

Heddy, S. 2002. Hormon Tumbuh. Raja Grafindo Persada. Jakarta

Khair, H., Meizal, dan R. H. Zailani. 2013. Pengaruh konsentrasi ekstrak bawang merah dan air kelapa terhadap pertumbuhan stek tanaman melati putih (Jasminum sambac L.). J. Agrium 18(2):130-138.

Lakitan, B. 1996. Dasar-Dasar Fisiologi Tumbuhan. Grafindo Persada. Jakarta

Lusiana., R. Linda, dan Mukarlina. 2012. Respon pertumbuhan stek batang sirih merah (Piper crocatum Ruiz dan Pav) setelah direndam dalam urine sapi. J. Protobiont 2(3): 157-160.

Leovici., H.D. Kastono, dan E.T.S. Putra. 2014. Pengaruh macam dan konsentrasi bahan organik sumber zat pengatur tumbuh alami terhadap pertumbuhan awal tebu (Saccharum officinarum L.) J. Vegetalika 3:(1): 22-34.

Marfirani, M. 2014. Pengaruh pemberian berbagai konsentrasi filtrat umbi bawang merah dan rootone-f terha- dap pertumbuhan stek melati "Rato Ebu". Lentera Bio 3(1):73-76.

Mayasari, E., L.S. Budiparmana, dan Y. S. Rahayu. 2012. Pengaruh pemberian filtrat bawang merah dengan berbagai konsentrasi dan rootone-f terhadap pertumbuhan stek batang tanaman jambu biji (Psidium guajava L.) J. Lenterabio 1(2):99-103.

Muswita. 2011. Pengaruh konsentrasi bawang merah (Allium cepa L.) terhadap pertumbuhan stek gaharu (Aquilaria malaccencis oken). J. Penelitian Universitas Jambi Seri Sains 13(1):15-20.

Mashudi, Adinugraha., D. Setiadi, dan A.F. Ariani. 2008. Pertumbuhan tunas tanaman pulai pada beberapa tinggi pangkasan dan dosis pupuk NPK. J. Pemuliaan Tanaman Hutan 2(2): 1-9.

Rahardja, P. C. dan Wiryanta. 2003. Aneka Cara Memperbanyak Tanaman. Agromedia Pustaka. Jakarta.

Rahayu, E. dan N. Berlian. 1999. Bawang Merah. Penebar Swadaya. Jakarta.

Sekta, N. D. 2005. Aplikasi ekstrak bawang merah dan air kelapa muda pada pertumbuhan bibit stek cabe jawa (Piper retrofractum Vahl.). http:// www.bdpunib.org. Diakses tanggal 04 Agustus 2015.

Siregar, A., P. E. Zuhry, dan Sampoerno. 2015. Pertumbuhaan bibit gaharu (Aquilaria malaccencis) dengan pemberian zat pengatur tumbuh asal bawang merah. J. Jom Faperta 2(1):1-2. 
Siskawati, E., L. Riza., dan Mukarlina. 2013. Pertumbuhan stek batang jarak pagar (Jatropha curcas L.) dengan perendaman larutan bawang merah (Allium cepa L.) dan IBA (Indol Butyric Acid). J. Protobiont 2(3):167170.

Siswanto, U., D. S. Nurmaini, dan A. Romeida. 2010. Penggunaan auksin dan sitokinin pada pertumbuhan bibit lada panjang (Piper retrofractum Vahl.) J. Tumbuhan Obat Indonesia 3(2):129-130.

Siswanto, U., Purwanto, dan Y. Widiyastuti. 2008. Respon Piper retrofractum Vahl terhadap aplikasi ekstrak bawang merah dan media. J. Tumbuhan Obat Indonesia 1(1):1-10.

Sudrajad, H., dan H. Widodo. 2011. Pengaruh konsentrasi dan lama perendaman rootone-f pada pertumbuhan pule pandak (Rauwolfia serpentina Benth). Seminar Nasional: Reformasi Pertanian Terintegrasi Menuju Kedaulatan Pangan. FP Universitas Trunojoyo. Surakarta.
Suhartono., R. A. S. Zead, dan A. Khoiruddin. Pengaruh interval pemberian air terhadap pertumbuhaan dan hasil tanaman kedelai (Glicine max (L) merril) pada berbagai jenis tanah. Embryo (1): 0216-0188.

Wiryanta, B.T.W. 2007. Membuahkan Anggur di Dalam Pot dan Pekarangan. Agromedia Pustaka. Jakarta.

Yuniastuti, E., B. A. P. Retno, dan K. Masruru. 2007. Pengaruh macam eksplan dan ZPT terhadap perbanyakan Adenium (Adenium obesum Roem. and Schuit.) secara in vitro. Agrosains J. Penelitian Agronomi 9(1):1-6. 